\title{
8. Where are the women candidates during elections? A Fiji media case study
}

\section{AABSTRACT}

This article examines the visibility of female election candidates, and females in general, in The Fiji Times and Fiji Sun during the 2006 general election. After analysing the data collected quantitatively, it can be concluded that female election candidates and females in general were virtually invisible in both the newspapers during the selected time period. The few articles published on or quoting women were mostly clichéd, lacked critical analysis and stereotyped them. An unexpected but equally important finding of the research sheds some light on the why of female election candidates' invisibility in the dailies during the election. The data show the extensive prominence Fiji's print media gave to race and coup-related issues as elections drew near, crowding out reportage of other major issues. Because of the fixation on race, the media overlooked many important issues, such as the fact that in all elections since independence, women have managed to secure fewer than 12 percent of parliamentary seats, even though they make up nearly half of the total population of the country. Such debates are rarely raised in the media.

Keywords: democracy, elections, Fiji, Fiji coups, gender, media representations, politics, race

SHAZIA USMAN

University of the South Pacific, Fiji

LL COUNTRIES want to be at the forefront of development. For a
country to progress, it first needs to acknowledge the areas in which
it is lagging behind and focus on addressing them by diverting resources to the problem and through other means. Fiji is one country that has faced many developmental problems. But regionally and internationally, it is considered the leader of developing countries in the Pacific region in terms 
of its economy, infrastructure and telecommunications. Despite its elevated status in the Pacific, half of Fiji's population-women - still remain underrepresented in the highest level of decision-making-Parliament.

History shows that Fiji's leadership has always been male-dominated. Given women's recognised importance in development in the region, how do the news media handle this issue? What is the media's stand? Do the media take up the cause in favour of women, or do they perpetuate the imbalance? Do the media play any part in the success or failure of women being elected into Parliament? This research addressed these questions by examining how the print media covered female political candidates in general elections.

Visibility of election candidates provided to the electorate by the media is important, as news media coverage during campaigns has important consequences for evaluations of women and men candidates (Norris, 1997, p. 12). In order to determine the role of print news media in Fiji during elections, this article will examine how much visibility newspapers accord female election candidates compared to male candidates. Visibility, in this instance, will be determined by how often female election candidates are quoted as opposed to male candidates; how often they are subjects of news items; and how often females in general are quoted in their professional capacity, as opposed to males. The research also aims to discover whether there are any issues that newspapers focus on that may hinder the development of gender equality in Parliament.

\section{Media and elections}

As political events occur, societies try to understand the effects and implications through the media. More often than not, it is the news media that individuals turn to for information. At the same time, most news consumers are not aware of the series of filters in place that shape the relationship between politics and the news media (Oates, 2008, p. 9).

During election campaigns, three of the most important political components in a country - the media, candidates and the voters - all intersect as public representatives are chosen through voting. In many countries around the world, elections are defined by the exchange of insults among political candidates (e.g., Fiji and the United States), and the proverbial horse-race ends with a collection of winners and losers, which is not always the best result in terms of organising political institutions for the long-term good of society. 
Election coverage is more often focused on the short-term elements of the campaign rather than the deeper issues confronting a nation, such as achieving gender equality in Parliament, the highest level of national decision-making.

In Fiji in particular, the issue of racial differences has always been a controversial topic but becomes more prominent in the media during elections. In every election the country has had since independence from the British in 1970, the tension between the majority indigenous Fijian population (referred to by a 2011 State decree as $i$-Taukei) and the slightly smaller Indo-Fijian community becomes more pronounced.

Do news media users decide who they are going to vote for after getting their information from the media? Do the news media have an effect on their audience in any way? No such studies have been done in Fiji, but several studies on voting behaviour since the World War in the United States and the United Kingdom suggest that many citizens are not particularly influenced by the scenes and drama of the election campaign itself. 'Rather, they rely on long-term political affinity and identification, which are formed from political socialisation in their early years' (Oates, 2008, p. 90 and Heywood, 2002, p. 242). According to Heywood (2002) the meaning of elections is closely linked to the factors that shape voting (p. 45).

Yet, as the 2004 United States presidential elections between George W. Bush, Jr. and John Kerry and the 2012 contest between Barack Obama and Mitt Romney have shown, close elections can often hinge on the persuasion of a relatively small number of voters. According to Latimer (1987), successful political communication starts with a realistic definition of the target audience (p. 805). At election time, the unstable voter who changes her/his decision is often the crucial component.

In Fiji's 2006 elections, the country's two dominant political parties - the Fiji Labour Party (FLP) and the Soqosoqo Duavata ni Lewanivanua Party (SDL) - went head to head. The SDL beat the FLP by only five seats (Summary of seats won so far, 2006). Various candidates won by small margins in their respective constituencies. Such results highlight the importance of campaigning and the role of the news media in swaying voters in modern politics.

Even if voters are not easily swayed into large ideological shifts by the media in election campaigns, the media still matter because:

They provide information to allow voters to match their preferences with particular candidates or parties; they give long-term political 
information that helps to socialise voters into particular party preferences; and in close elections or in critical issues when voters are confused or even angry, media coverage can sway an election. (Oates, 2008, p. 92)

Despite some misgivings about media performance from time to time, there are no better alternatives to disseminating messages about candidates and parties during elections (McQuail, 1994, p. 67). While political parties in Fiji pursue direct contact with their potential voters through rallies and constituency visits, media coverage remains a particularly influential part of an election effort when it comes to reaching out to the masses.

\section{Ideological bias in the media}

Incorporated in all news reporting is some version of the norm: of what usually happens or how people usually behave. These norms are based on the assumption that something is newsworthy; that is, it is both out of the ordinary and also part of the general framework of expectations. These assumptions are grounded in ideologies which seek to explain the way the world works.

Norris (1997) suggests that the media norm may disadvantage women. Firstly, their activities receive less coverage than men's; secondly, descriptions of them refer to their appearance or to the men in their lives (that is, they are not accorded an independent existence). Such representations articulate a particular ideological view about men and women (p. 167). Norris' observations call for a deeper look into how women are represented in the media, which is the main focus of this research paper.

\section{Gender and the news media}

A wide variety of demographic and political characteristics have been shown to affect attitudes about women in office. Among the variables demonstrated to predict attitudes about women candidates, gender has been the best documented (Falk \& Kenski, 2006). Feminist media scholars since the early 1970s have had an interest in whether and how major news media cover women's experiences, issues and events (Byerly \& Walker, 2000). News has been the major focus because it is the major source of information, facts, ideas and opinion for people throughout the world. In today's 24-hour news environment, it matters who and what is selected to appear in the news, and how individuals and events are portrayed. Equally, it matters who is 
left out and what is not covered (World Association for Christian Communication, 2005). The most extensive indicator of women's place in the news (McGregor \& Comrie, 2002) is the 2010 Global Media Monitoring Project (GMMP), a world-wide effort by 108 countries, including Fiji, to document news media coverage of women on one particular day-November 10, 2009. The results showed that the status of women in the world's news media had changed little since 1995, when the initial project took place. Worldwide, women comprised just 24 percent of news subjects and men 76 percent (in 2005, women were 21 percent and men 79 percent; in 2000, women were 18 percent and men 82 percent; in 1995, women were 17 percent and men 83 percent). In 2010 the proportion of female news subjects in politics was 19 percent (to 14 percent in 2005; 12 percent in 2000; and 7 percent in 1995) (World Association for Christian Communication, 2010 \& 2005, p. 22; and McGregor \& Comrie, 2002, p. 250).

While Australia, Fiji and New Zealand had been participating in the monitoring since its inception, Papua New Guinea and Tonga joined in 2009. In that same year, the results of the Fiji survey showed that 18 percent of all news subjects on television were women. Figures for the same period showed that of all news subjects on radio and newspapers, women accounted for 14 and 40 percent, respectively. When breaking the figures into topics, none of the news subjects in political and government-related stories were women. Fiji women as news subjects figured below men in all topics (politics, government - 0 percent; crime, violence-22 percent; social, legal-20 percent; celebrity, arts, sport -40 percent and the Girl-Child — 0 percent) (World Association for Christian Communication, 2010).

In 2005, 11 percent of all news subjects on television in Fiji were women on television (global average: 22 percent), 27 percent radio (global average: 17 percent) and 20 percent print (global average: 21 percent). When breaking down the figures into topics, only 18 percent of all news subjects in political and government-related stories were women. Fiji women as news subjects figured below men in all topics (politics, government-18 percent; economy, business - 6 percent; crime, violence - 30 percent; social, legal-27 percent; celebrity, arts, sport-13 percent and science, health -42 percent) (World Association for Christian Communication, 2005, p.124).

Even when women were the subjects of news, their representation was not on a par with men's. No woman's opinion served as the popular opinion 
and no woman related her personal experience in a story. Sixty-seven percent of women served as eye-witnesses in stories; while only 10 percent were the main subjects of the story. Forty percent gave their expert opinions; and 39 percent served as spokespersons (World Association for Christian Communication, 2005, p. 129). Overall the global figures were not as dismal as Fiji's, but even then, women were below men in all categories.

According to the then Fiji Media Watch vice-president Peter Emberson, who co-monitored the Fiji project in 2005:

In Fiji, 49 percent of the population is women, but only 20 percent of the people featured in the news are women. And it is the same the world over. Twenty percent includes those who work in the news, those who present the news and the subjects of the news. It is predominantly a male scenario that you are looking at. We are telling stories about men in the news; we see the predominant role that men play for expert commentary, as eye-witnesses, as news subjects it is predominantly male. It is pretty much a slice of what happens every day in the news. (Pacific Media Watch, 18 February 2006)

Media researcher Julie Middleton (2008) challenged Pacific journalists 'to provide genuine space for women's voices and involvement in all types of coverage, a provision built on the conviction that women are equal partners in development and in the media' (p. 43). She further added:

The media-newspapers, radio, television, the advertising industry and the internet - are a crucial part of the development equation, with the power to set agendas, hold governments to account, and influence the way women, their rights and interests are represented. (Middleton, 2008, p. 43)

What difference do these coverage patterns make? Nancy Woodhull, founding editor of USA Today, believes it makes a tremendous difference. According to her 'there is an act called symbolic annihilation. It means that if the press does not report existence, for all perception purposes, you do not exist. It's called feeling invisible' (Woodhull in Miller, 1996, p. 513).

\section{Female election candidates and the media}

Recent studies clarify the powerful role the news media can play in campaigns; the media can influence what voters learn about candidates as well 
as the criteria voters use when evaluating candidates (Kahn \& Goldenberg, 1991). By covering male and female candidates differently, the news media may influence the success or failure of female candidates for public office (Kahn \& Goldenberg, 1991). There are four ways in which the news media can contribute to shaping the attitudes of voters towards candidates. Firstly, by influencing both the amount and type of information the voters acquire about the elected officials. Secondly, they may persuade voters to support or oppose certain candidates. Thirdly, they may set the agenda for a political campaign by deciding which issues people will consider most important and finally, by altering the criteria people use to evaluate public officials by emphasising certain issues over others (as quoted in Maytal, 2005, p. 7). If women are, in fact, being unfairly portrayed by the media, then it can be inferred that the media may be hindering the ability of women to obtain political office, retain political positions, and be promoted in politics (Kahn \& Goldenberg, 1991, p. 180 and Maytal, 2005, p. 7). As Kahn explained:

By differentiating between male and female candidates in their coverage, the press may encourage voters to develop more favourable impression of certain candidates and less favourable images of others. The media representation of a candidate's campaign may therefore influence the electability of candidates. (As quoted in Maytal, 2005, p. 7)

\section{Visibility of female election candidates}

Since name recognition is an important advantage for any election candidate, it is imperative for female candidates to be highly visible in the media because 'voters will rarely support a candidate they do not recognise' (Kahn \& Goldenberg, 1991, p. 184). Since the amount of coverage a candidate receives is related to the voters' recognition of the candidate, gender differences in press attention may be consequential. Standard definitions of news may lead reporters and editors to see female candidates as especially newsworthy and female candidates may therefore receive more attention in the news (Norris, 1997). On the other hand, if reporters and editors regard female candidates as less viable and thus less important than their male counterparts, then female candidates may receive less news exposure (Kahn \& Goldenberg, 1991).

The number and placement of newspaper articles on female election candidates indicate the seriousness with which the media consider this group 
and may send a potentially-powerful message to readers. If female election candidates are included more frequently and on the front pages, this may signal that women are significant and important political players; if they are covered infrequently and relegated to the fashion section, readers may well get the impression that the presence of these potential Members of Parliament are unimportant and their contributions are marginal (Norris, 1997). It is also important that female election candidates not only get adequate coverage in the media to secure voter recognition but also that the substance of their campaign be adequately covered as this may influence voters' evaluation of the candidates (Kahn \& Goldenberg, 1991).

The discussion so far suggests that voters, by and large, have a difficult time acquiring information about female candidates because of the way media tend to portray them. The lack of available information about female candidates may result in inadequate/poor/non-existent voter recognition, and consequently, may limit a woman's election chances (Kahn \& Goldenberg 1991). As Jennifer Pozner explained, that 'by determining who gets to speak and who is excluded... as well as which issues are discussed and how they are framed, the media has [sic] the power to maintain the status quo or challenge the dominant order' (as quoted in Maytal, 2005, p.6).

\section{Status of women in Fiji}

In many societies in the developing world women do not enjoy the same opportunities as men. They bear children and are their care-givers; they maintain households, produce food for maintaining families and also act as keepers and transmitters of tradition and culture. They work long hours and are paid less than men; they have limited opportunities and their choices are constrained by social, cultural and religious beliefs. Men are overseers of all these roles and activities because religion, cultural systems, traditional beliefs and the patriarchal nature of the society demand and reinforce their dominance. Men also have relatively more opportunities and choices available to them. These disparities generate substantive gaps for women, who lag behind in education, employment and social and political decision-making processes (Chandra \& Lewai, 2005, p. 1).

Women's contribution, like that of men, is crucial for the social, economic and political development of Fiji and for achieving gender equity and equality at all levels in society. Although women form half of the total population of 
Fiji, they remain unequal partners and get unequal benefits from the developmental process (Chandra \& Lewai, 2005; Nicholl, 2006, \& Narsey, 2007).

According to the 2007 census report the Republic of Fiji Islands has a population of 837, 271 with 410, 095 women (Fiji Bureau of Statistics, 2007 Facts and Figures). The female literacy rate is 91 percent and the male is 95 percent (Nicholl, 2006, p. 88). Despite these statistics women's role in decision-making at the highest level is minimal in Fiji (Nicholl, 2006, p. 88).

Women in postcolonial Fiji have taken an active role in political events via voting and supporting male candidates in elections. They have supported men in positions of power in the Parliament and the government for decades but their active participation in the government as politicians has remained limited, with the exception of women of privileged traditional and chiefly status (Chandra \& Lewai, 2005, p. 122 \& Siwatibau et al., 2006, p. 12). Historically, Fiji has had a number of influential women leaders (including the late India-born Irene Jai Narayan). They have-until recently-either been chiefs themselves or have come from chiefly families and enjoyed high status among the indigenous people. Voting for such women is culturally acceptable (Nicholl, 2007, p. 162 and Siwatibau et al., 2006, p. 18). Chiefly women like Adi Asenaca Caucau, Adi Koila Nailatikau, Ro Teimumu Kepa, Adi Samanunu Talakuli Cakobau and Adi Kuini Speed have been ministers since the last three elections. But even chiefly female ministers have been confined to positions traditionally considered 'feminine', such as health, education and social welfare (Chandra \& Lewai, 2005, p. 122).

The first Alliance government that ran the country after independence had only one woman member (Siwatibau et al., 2006, p.12). The number of women in Parliament has never risen above eight at one single time. This is a clear indication of how weak national will has been in ensuring the achievement of gender equality at all level of decision-making.

The lack of women in decision-making positions has not gone unnoticed by the country's women's movement. In 2006, four non-governmental organisations jointly advertised in the daily newspapers about the importance of voting and reminded women that their 'vote was secret and that no one needed to know how they had cast their ballot'. In addition to assisting with the advertisements, femLINKPACIFIC: Media Initiatives for Women-a women's media organisation - broadcast interviews with women candidates and covered issues concerning the election (Nicholl, 2007, p. 168). The Fiji Women's 
Rights Movement (FWRM), organised a Women in Politics Appeal-where individuals and organisations were encouraged to make cash donations, which would later be divided equally among female election candidates, regardless of party affiliations or financial background.

In addition, FWRM produced an A4 size flyer entitled 'Women Ask' which was inserted into the Fiji Times on Saturday 6 May, 2006 - the first day of voting (Nicholl, 2007, p. 168 \& Fiji Women's Rights Movement, 2008). According to FWRM, the flyer was a summary of a Women's Ask survey that was conducted between the months of April and May 2006 to inform the people of Fiji, especially women, on the stance that different political parties were taking regarding women's issues:

FWRM felt that such information on each political party's commitments to women would not be covered in such detail by the news media. Thus, FWRM saw the need to print and pay for the insert of the flyers, so that voters would have the chance to evaluate political parties using this detailed information. (Fiji Women's Rights Movement, 2008)

\section{Possible reasons for lack of women in Fiji Parliament}

There are three possible reasons why there are so few women in Fiji's Parliament - the country's cultural environment; the nature of its political parties and electoral systems; and its media playing a significant partin electoral success.

\section{Cultural environment}

The lack of women in the higher echelons of decision-making can be attributed to culture and tradition, which reinforce patriarchy (Siwatibau et al., 2006 , p. 14). As a result of the patriarchal system, there has been a general acceptance by both men and women that politics is the domain of men, and over the years, this attitude has been proven difficult to alter. Many women do not get a straight passport to equality and the opportunity to make decisions at the national level despite being educated (Usman, 2008, p. 60).

According to Dame Carol Kidu, Papua New Guinea's former Community Development Minister, the Pacific region has always had the lowest world percentage of women in politics and is the only region that has shown no improvement in spite of almost two decades of global activism (Fiji Times, 2008a, p. 24). In a keynote address at the Asia Pacific Forum on Women, Law 
and Development in Bangkok in 2008, Dame Kidu said the contemporary culture in the Pacific still tended to be conservative and patriarchal. It reflected a colonial and missionary heritage as well as a reluctance to change a status quo that favoured men politically, socially, economically and administratively.

Nature of political parties and electoral systems

Fiji's culture also permeates to the foundations of the country's political parties and electoral systems. As part of a report entitled Developing a more Facilitating Environment for Women's Political Participation in Fiji by Siwatibau et al. (2006), a survey was conducted to ascertain the reasons for the lack of women in Fiji's Parliament. One of the major reasons identified was women's (and men's) hesitancy in women joining political parties because of the 'way they are run and that they do not provide a friendly or conducive environment for women to join' (Siwatibau et al., 2006, pp. 14-15).

Similarly, the type of electoral system in a country also plays an important role in women's political representation. While not specifically advocating for any particular electoral system, the Director-General of the Secretariat of the Pacific Community (SPC), Dr Jimmy Rodgers, believes that in order to increase women representatives in Pacific Parliaments, electoral reforms must seriously be considered. He suggested electing a male and a female member for each constituency represented in Parliament (Osifelo, 2008).

Nicholl (2006) in her analysis of Fiji and its Alternative Vote electoral system concluded that 'women perform better under proportional representation, especially list systems, and that single member constituency system is the worst for women' (pp. 101-102).

\section{Invisibility in the Fiji media}

Aside from culture, the nature of the political parties and electoral systems, the media also play a critical role in the electoral success of political candidates. According to FWRM, as party and political power tends to be largely held by men and male candidates, they get the lion's share of media coverage. This leads to women candidates and women's issues being neglected (Fiji Women's Rights Movement, 2008). The virtual invisibility of women in the Fiji media cannot be helpful in getting women elected in Parliament as Fiji's print media (predominantly its newspapers) play a crucial part in informing the public on the day-to-day events occurring in the country.

Women forging new political ground often struggle to receive media 
coverage and legitimacy in the eyes of the media and, subsequently, the public (Carroll \& Fox, 2006, p. 171). How can the public vote for female candidates when they never appear in the news? FWRM and other women's organisations have raised the problem of the 'invisibility' of women candidates and women's issues during elections.

\section{Fiji: A historical background, racism, media and the state}

When discussing the low levels of women's representation in Parliament, as well as the virtual invisibility of women in the media, especially during election times, it is important to understand the historical background of the particular country. It is also important to identify the framework within which the media in that country works. As such, this section discusses the issue of racial politics within Fijian society since politics dominates issues covered by media in Fiji. It also discusses whether the media's preoccupation with racial politics may have crowded out other important issues such as lack of women in decision-making.

In Fiji, both indigenous Fijian and Indo-Fijian politicians use race as a major strategy in their election campaigns because of the race-based political electoral system. The Fiji Times, often accused of fuelling racial politics in Fiji through its allegedly biased reporting, said in an editorial on Barack Obama's first election as United States President that there were 'lessons to be learned'. It claimed:

Fiji's politics has always been about two things-race and political parties. In every election from 1972 to 2006 there were two major political parties with supporters from one of the two larger racial groups. Of course, each party publicly espoused multiculturism and equality. But behind the scenes and on election flyers the parties fanned the fires of racial mistrust in the attempt to gain a few more votes. (Fiji Times, 2008c, p.6)

The media's preoccupation with race, especially during election times, blocks out issues such as the representation of women in Parliament and other decision-making bodies. There have been few attempts at a media campaign to educate people about the need to have more women in decision-making positions as the space is filled up by reporting of political and racial rhetoric, which is perceived as more newsworthy. 
In a bid to regulate the media industry in 2003, Prime Minister Laisenia Qarase proposed a Media Council of Fiji Bill. Caretaker Minister for Information Marieta Rigamoto, said 'politics was a fact of life and in some instances, the media has [sic] served to harden racial differences between the two races and that was how some people perceived the political situation in the country (Fiji Times, 2006, p. 4). The Fiji Times editorial and training manager, Steve McCully, rejected the claims and said Rigamoto did not understand the role of the media or the laws governing it (Fiji Times, 2006, p. 4).

Mahendra Chaudhry, the then-Interim Finance Minister, said that the Fiji media should be licensed because they were 'divisive, racist and biased' (Radio Fiji, 2008). But The Fiji Times editor-in-chief, Netani Rika, defended his article, saying the paper had consistently run news articles critical of the current administration. According to him, it gave the same critical coverage when 'Qarase, Chaudhry and Rabuka governments were in power'. These examples show how politically-active the media is, to the point of clashing with government ministers as part of their essential Fourth Estate role, except that most other issues seem to get swept aside.

On 10 April 2009, the military government instituted the Public Emergency Regulation (PER) decree to prohibit public gatherings for the purpose of political meetings. The decree stopped the media from broadcasting or printing material which might incite the people. This was followed by the Media Industry Development Decree in 2010, which put media outlets under strong censorship control.

A cursory glance at both The Fiji Times and Fiji Sun, show a marked increase in human interest stories but on the negative side there is rarely any critique of the State. In other words, the Fourth Estate function of media is crucial but so are development issues - you cannot have one without the other. A healthy balance of both would be the ideal.

\section{Research methodology}

The article now turns to an analysis of the data collected using the Global Media Monitoring Project (GMMP) methodology which was adapted for analysis of the data since it is mainly concerned with the visibility of women in news. However, since this research is only concerned with the print media coverage of female election candidates in 2006, the GMMP framework was modified. 
The two national newspapers selected for analysis are The Fiji Times and the Fiji Sun. The Fiji Times was chosen because it is Fiji's oldest newspaper with the largest circulation (audited circulation 20,630) and the strongest reputation for news. The Fiji Sun (un-audited circulation 20,000) was chosen because in recent years it has been The Fiji Times' strongest competitor. The Fiji Daily Post (circulation unknown) was not chosen for analysis because of its tabloid-style writing, its negligible circulation and the fact that it has had its operations halted on several occasions due to financial difficulties. It has since closed.

The time period chosen for the analysis was 26 April 2006, to 5 May 2006. The last 10 days before voting began were analysed because of the increase in the intensity of campaigning. Political parties, candidates and the media start focusing on the most important issues as the voting period draws near and it will be prudent to analyse which candidates and what issues were given more coverage.

All election-related items - that is, news stories appearing in any section of the newspaper and all election-related editorials, commentaries and opinion pieces (not letters) during the stated time period were coded for analysis. Letters to the editor; cartoons; advertising (both normal and election-related); story listings on the front page or inside pages of newspapers; jokes; and weather reports, were not coded (though stories about the weather-a flood, heat wave, drought etc - that are election-related are coded).

In the 2006 elections, 338 candidates stood for elections - 308 were males and 30 females.

\section{Findings}

Data collected are depicted in the selected graphs. Graph 1 shows the number of times both female and male election candidates were quoted directly, or indirectly; or were significant enough to be mentioned in items during both time periods, in both newspapers.

Graph 1 shows, The Fiji Times only quoted female candidates 20 times in 2006. The Fiji Sun in 2006 also had similar results-it only quoted female election candidates 29 times, compared to 292 times for the male candidates. The results depicted in Graph 1 are a clear indication that female election candidates were given less coverage by both The Fiji Times and the Fiji Sun in the last 10 days before voting began in 2006. 
Graph 1: Election candidates quoted in the Fiji Times and Fifi Sun

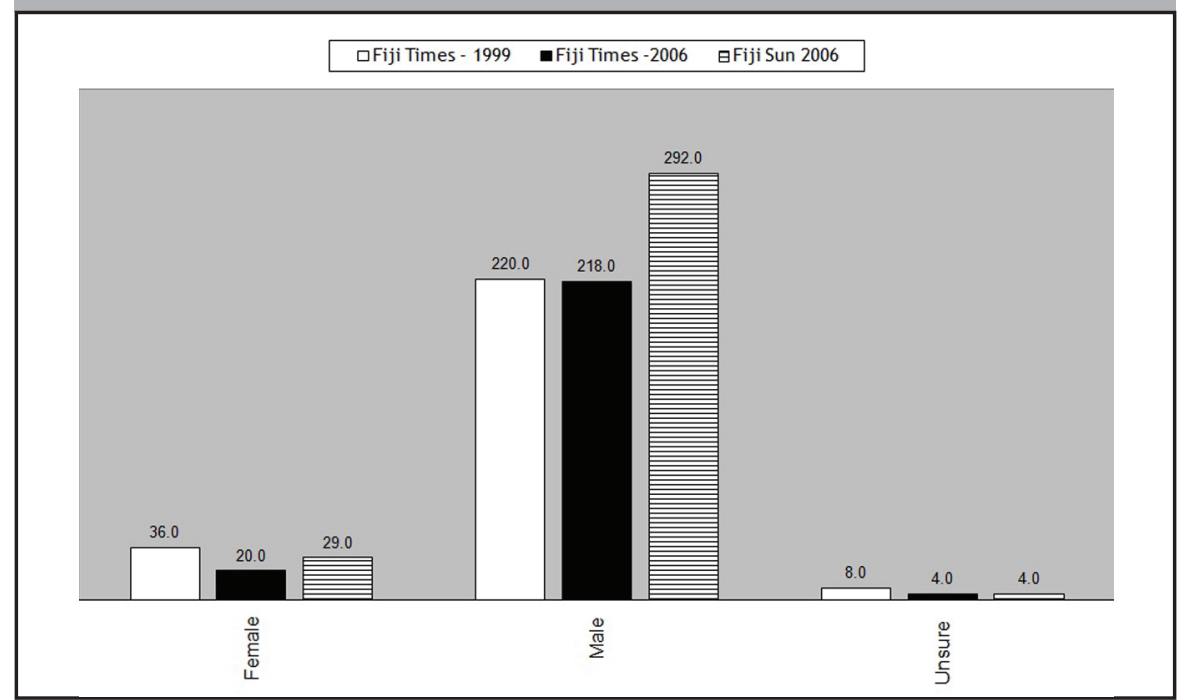

Source : Number of times female and male election candidates were quoted directly, indirectly or were significant enough to be mentioned in both newspapers.

Table 1 answers the question of what functions (roles) females and males played in election-related items. The data show that in all functions, males have a clear majority ( 87.6 percent). It is the male that is usually the subject of an item, the spokesperson, the expert, the person who gives personal or popular opinion, and the eye-witness. Females are only the subject of an item

\section{Table 1: Function of male and female in election-related items}

\begin{tabular}{|l|c|c|c|c|}
\hline Function & $\mathrm{n}$ & Female $\%$ & Male \% & Not known \% \\
\hline Do not know & 25.0 & 20.0 & 80.0 & 0.0 \\
\hline Subject & 376.0 & 12.2 & 87.2 & 0.5 \\
\hline Spokesperson & 389.0 & 7.5 & 91.8 & 0.8 \\
\hline Expert or commentator & 13.0 & 15.4 & 84.6 & 0.0 \\
\hline Personal experience & 17.0 & 11.8 & 82.4 & 5.9 \\
\hline Eye witness & 1.0 & 0.0 & 100.0 & 0.0 \\
\hline Popular opinion & 10.0 & 10.0 & 90.0 & 0.0 \\
\hline $\begin{array}{l}\text { There is no specific person } \\
\text { in the story }\end{array}$ & 14.0 & 0.0 & 0.0 & 100.0 \\
\hline TOTAL & 845.0 & 10.1 & 87.6 & 2.4 \\
\hline
\end{tabular}


12.2 percent of the time. Table 1 shows that males were quoted more often than females and this was the same for both newspapers.

\section{Conclusion}

Overall the results paint a dismal picture of the status of women as reflected in Fiji's print media. The first important conclusion is the virtual invisibility of female election candidates, and females in general, in both The Fiji Times and the Fiji Sun during the survey period. Findings show that in every category from which data were analysed, female election candidates and females in general were far less visible than men. This is a breach of Article 23 of the Media Council General Media Code of Ethics \& Practice (9): media should endeavour to show fairness, impartiality and balance when presenting news which deals with political matters.

What are the implications of these findings for the media? The literature tells us media have the potential to assist female election candidates get better and fairer coverage but are currently not doing this (Kahn \& Goldenberg, 1991). The print media in Fiji have rendered female election candidates invisible. This could affect their chances of winning seats as they would not be recognised by potential voters.

Chiefly women in Fiji who stand for elections seem to have an advantage over Indigenous Fijian women of non-chiefly status and Indo-Fijian women. Voting for them appears to be culturally acceptable, even culturally obligatory. It is the media's responsibility, as the Fourth Estate, to ensure that adequate coverage is given to all women candidates and not just the chiefly ones as shown by this research. The media should not be giving undue prominence to individuals deemed to be of higher class in the Fijian society.

This finding is worrisome because it gives the indication that in Fiji only men can be reliable and accessible sources of information. It indicates that there may be no or few professional women who can comment on issues. The impression given is that women's expertise is not as good as that of their male counterparts.

By 2009, the print media in Fiji had shown themselves more capable of covering development-related stories. This, however, should not have to be at the expense of political reporting, in the same way as the article has argued that political reporting and the focus on racial politics should not be at the expense of covering women in politics, public life and decision making. Much 
has been said about the power of the news media and the many influences they have over their audience. It is now time for the media to start offering their audience more in-depth reporting on issues such as gender equality, and be more diligent in giving voice to the opinions and comments of the many educated, intelligent and powerful women on general matters. If Fiji wants to progress and transcend the politics of race and gender discrimination in all aspects of life, the mindset of its people needs to change. The media can play an instrumental role in this regard if they first rid themselves of their prejudices.

\section{References}

Australian Broadcasting Corporation, (2009, April 15). Free speech nothing but trouble: Bainimarama. Retrieved on May 22, 2009, from www.abc.net.au/news/ stories/2009/04/15/2543115.htm

Buadromo, Virisila (2009). The impact of Fiji's 2006 coup on human and women's rights. In J. Fraenkal, S, Firth and B. V. Lal (Eds.), The 2006 military takeover in Fiji: A coup to end all coups? Canberra: ANU E-Press.

Byerly, C., and Walker, D. (2000). Ignoring international Women's Day 2005: A qualitative analysis of US news coverage. Conference Papers-International Communication Association: 1-24. Communication and Mass Media Complete. Retrieved on August 12, 2008, from EBSCOhost.

Carroll, S., and Fox, R, (Eds.) 2006. Gender and elections: Shaping the future of American politics. Cambridge: Cambridge University Press.

Chandra, D., and Lewai, V. (2005). Women and men of Fiji islands: Gender statistics and trends. Suva: Population Studies Programme (USP).

CNN.com Election Results, (2004). CNN. Retrieved on December 21, 2009, from www.cnn.com/ELECTION/2004/pages/results/

Falk, E., and Kenski, K. (2006). Issue saliency and gender stereotypes: Support for women as presidents in times of war and terrorism. Social Science Quarterly, 87(1), 1-18. Academic Research Library database. Retrieved on August 11, 2008, from EBSCOhost.

Fiji Times, (2006, April 15). State explains media freedom. p. 4. Retrieved on May 22, 2009, from http://proquest.umi.com/pqdweb?did=1044240361\&sid=7\&Fmt= $3 \&$ clientId $=34259 \&$ RQT $=309 \&$ VName $=P Q D$

Fiji Times, (2008a, June 11). Five island states have no women in politics. p. 24. Retrieved on July 22, 2013, from www.fijitimes.com/story.aspx?id=91910

Fiji Times, (2008b, July 22). Chaudhry claims bias robs people of news. p. 4. Retrieved on May 22, 2009, from http://proquest.umi.com/pqdweb?did=1514259751\&sid= $4 \&$ Fmt $=3 \&$ clientId $=34259 \&$ RQT $=309 \&$ VName $=$ PQD

Fiji Times, (2008c, November 7), editorial: Lessons we must learn, p. 6

Fiji Women's Rights Movement. (2008, August 28). Re: Information on Women Ask Project. Email to Tara Chetty. 
Heywood, A. (2002). Politics, [2nd Ed.]. New York: Palgrave Foundations.

Kahn, K., and Goldenberg, E. (1991). Women candidates in the news: An examination of gender differences in US Senate campaign coverage. Public Opinion Quarterly 55(2), 180-199. Communication and Mass Media Complete. Retrieved on August 12, 2008, from EBSCOhost.

Latimer, M. (1987). The floating voter and the media. Journalism Quarterly, 64(4), 805-819. Communication and Mass Media Complete. Retrieved on August 12, 2008, from EBSCOhost.

Maytal, A. (2005). Media coverage of female politicians in the 108th Congress: Has anything changed since the 'Year of the Woman'? Media Report to Women, 33(3), 6-13. Academic Research Library database. Retrieved on August 10, 2008, from EBSCOhost.

McGregor, J., and Comrie, M, (Eds.). 2002. What's news: Reclaiming journalism in New Zealand. Palmerston North: Dunmore Press.

McQuail, D. (1994). Mass communication theory — an introduction [3rd Ed.]. London: SAGE Publications Ltd.

Middleton, J. (2008). Gender, media and development: What's the connection? In S. Singh., and B. Prasad (Eds.), Media and development: Issues and challenges in the Pacific Islands (pp. 43-58). Lautoka: Fiji Institute of Applied Science.

Miller, P. (1996). Teaching women in the news: Exposing the invisible majority. PS, Political Science \& Politics, 29(3), 513-517. Academic Research Library database. Retrieved on August 10, 2008, from EBSCOhost).

Mukda-anan, R., Kusakabe, K., and Komolsevin, R. (2006). The Thai vernacular press and the woman politician: Stereotypical reporting and innovative response. Asian Journal of Communication, 16(2), 152-168. Communication and Mass Media Complete. Retrieved on August 12, 2008, from EBSCOhost .

Narsey, W. (2007). Gender issues in employment, underemployment and incomes in Fiji. Suva: Vanuavou Publications.

Nicholl, R. (2006). Electing women to Parliament: Fiji and the alternative vote electoral system. Pacific Journalism Review 12(1), 87-107. Communication and Mass Media Complete. Retrieved on September 12, 2008, from EBSCOhost .

Nicholl, R. (2007). Broken promises. In J. Fraenkal, and S. Firth (Eds.), From election to coup in Fiji: The 2006 campaign and its aftermath, Canberra: ANU E Press and Asia Pacific Press.

Norris, P, (Ed). (1997). Women, media and politics. Oxford: Oxford University Press. Oates, S. (2008). Introduction to media and politics. London: SAGE Publications Ltd. Osifelo, E. (2008, November 8). Rodgers calls for more women in parliaments. Solomon Star News. Retrieved on November 11, 2008, from http://solomonstarnews.com/index.php?option=com_content\&task $=$ view\&id $=4627 \&$ Itemid $=26$

Pacific Media Centre, (2009, April 12). PMC condemns 'ruthless censorship' in Fiji. Retrieved on May 22, 2009, from http://pacificmediacentre.blogspot.com/2009/04/ pmc-condemns-ruthless-censorship-in.htmlt

Pacific Media Watch, (2006, Feb 18). New report shows marginalisation of women. Retrieved on September 7, 2008, from http://pmw.c2o.org/2006/fiji4881.html 


\section{MEDIA AND DEMOCRACY IN THE PACIFIC}

Perrottet, A., and Robie, D. (2011). Pacific media freedom - A status report. Pacific Journalism Review, 17(2), 148-168. Retrieved on July 1, 2012, from http://aut. academia.edu/DavidRobie/Papers/1048775/Pacific_media_freedom_2011_A_ status_report

Radio Fiji, (2008, March 19). Fiji's media labelled 'divisive and racist'. Retrieved on May 22, 2009, from www.radiofiji.com.fj/fullstory.php?id=9568

Rika, N. (2009, May 10). Courage under fire. Samoan Observer. Retrieved on May 22, 2009, from http://kauri.aut.ac.nz:8080/dspace/bitstream/123456789/2256/1/ RIKA_SPEECH_MAY2009_PFF.pdf

Robie, D. (2001). Coup coup land: The press and the putsch in Fiji. Asia Pacific Media Educator, 10,148-162. Retrieved on May 22, 2009, from www.pmc.aut. ac.nz/docs/papers/coupcoupland_apme01.pdf

Robie, D. (2004). Mekim Nius: South Pacific media, politics and education. Suva: USP Book Centre. Retrieved on May 22, 2009, from http://www.pmc.aut.ac.nz/ docs/papers/coupcoupland apme01.pdf

Siwatibau, S., Johnston, R., Khan, N and Whippy, N. (2006). Developing a more facilitating environment for women's political participation in Fiji. Suva: UNIFEM.

Stuff, (2009, April 15). Bainimarama's actions attract support. Retrieved on May 22, 2009, from www.stuff.co.nz/world/south-pacific/2337088/Bainimaramas-actionsattract-support

Summary of seats won so far. (2006). Elections 2006 Fiji Island. Retrieved on December 6, 2009, from www.elections.gov.fj

Usman, S. (2008, September). Fighting for gender equality: The difference between sex and gender. MaiLife, p. 60.

World Association for Christian Communication. (2005). The Global Media Monitoring Project. London: WACC.

World Association for Christian Communication. (2010). The Global Media Monitoring Project. London: WACC.

2007 Facts and Figures. (2007). Fiji National Census of Population 2007: Fiji Bureau of Statistics. Retrieved on October 27, 2008, from www.statsfiji.gov.fj

Shazia Usman is a Masters in Pacific Media Studies graduate from the University of the South Pacific. She currently works at the Fiji Women's Rights Movement as its communications officer. She was a Journalism Education Association of Australia scholarship winner and presented an earlier version of this paper at the JEAA in Melbourne, Victoria, in November 2012. zia_rockz@yahoo.com 